\title{
Sediment Transport Model for a Surface Irrigation System
}

\author{
Damodhara R. Mailapalli, ${ }^{1}$ Narendra S. Raghuwanshi, ${ }^{2}$ and Rajendra Singh ${ }^{2}$ \\ ${ }^{1}$ Biological Systems Engineering, University of Wisconsin, Madison, WI 53706, USA \\ ${ }^{2}$ Agricultural and Food Engineering Department, Indian Institute of Technology, Kharagpur 721302, India \\ Correspondence should be addressed to Damodhara R. Mailapalli; dam.iitkgp@gmail.com
}

Received 16 March 2013; Revised 25 June 2013; Accepted 11 July 2013

Academic Editor: Keith Smettem

Copyright (c) 2013 Damodhara R. Mailapalli et al. This is an open access article distributed under the Creative Commons Attribution License, which permits unrestricted use, distribution, and reproduction in any medium, provided the original work is properly cited.

\begin{abstract}
Controlling irrigation-induced soil erosion is one of the important issues of irrigation management and surface water impairment. Irrigation models are useful in managing the irrigation and the associated ill effects on agricultural environment. In this paper, a physically based surface irrigation model was developed to predict sediment transport in irrigated furrows by integrating an irrigation hydraulic model with a quasi-steady state sediment transport model to predict sediment load in furrow irrigation. The irrigation hydraulic model simulates flow in a furrow irrigation system using the analytically solved zero-inertial overland flow equations and 1D-Green-Ampt, 2D-Fok, and Kostiakov-Lewis infiltration equations. Performance of the sediment transport model was evaluated for bare and cropped furrow fields. The results indicated that the sediment transport model can predict the initial sediment rate adequately, but the simulated sediment rate was less accurate for the later part of the irrigation event. Sensitivity analysis of the parameters of the sediment module showed that the soil erodibility coefficient was the most influential parameter for determining sediment load in furrow irrigation. The developed modeling tool can be used as a water management tool for mitigating sediment loss from the surface irrigated fields.
\end{abstract}

\section{Introduction}

Surface irrigation is a widely used farming system for crop production as it requires less skilled labour and involves less operational cost. Surface irrigation systems contributed to about $90 \%$ of the world's crop land irrigation promoting furrow irrigation as the main application method [1]. However, poor design and management, nonuniformity of water application, and over-irrigation featured in surface irrigation are responsible for inefficient irrigation, leading to wastage of water, water logging, salinization, and pollution of surface and ground water resources. Irrigated agriculture is under serious risk due to substantial soil losses from highly erodible soils [2-4]. The sediment transport in an irrigation season varies with the number of previous irrigations, flow rate, soil type, field slope, and field length $[5,6]$. Berg and Carter [2] reported annual losses of sediments ranging from 1 to $141 \mathrm{Mg} \mathrm{ha}^{-1}$ in Southern Idaho. Koluvek et al. [7] measured 0.2 to $50 \mathrm{Mg} \mathrm{ha}^{-1}$ of soil loss per season in Washington and 1 to $22 \mathrm{Mg} \mathrm{ha}^{-1}$ per irrigation in Wyoming. Brown et al. [8] observed a maximum sediment loss of $79.5 \mathrm{~kg}$ per furrow for $4 \%$ slope and $26.4 \mathrm{~kg}$ per furrow for $1.6 \%$ slope in an irrigation event. Mailapalli et al. [6] estimated as $0.4 \mathrm{Mg} \mathrm{ha}^{-1}$ of soil loss for bare and $0.2 \mathrm{Mg} \mathrm{ha}^{-1}$ for cropped furrow fields in an irrigation event. Sediment flow from agricultural fields can cause downstream water quality degradation and eutrophication by carrying soil and plant nutrients and other pollutants.

Amount of soil loss from a furrow depends on furrow stream size, velocity, and soil susceptibility to erosion (erodibility). In furrow irrigation, water delivered through siphon tubes or gated pipes picks up soil particles and carries them down the furrow. The furrow stream continues to pick up sediments until its energy equals to that needed to carry soil particles. Furrow stream size and velocity decrease with the waterfront advance along the furrow due to water loss as infiltration. At some point along the furrow, the capacity of the flow to transport the accumulated sediment decreases and the net deposition occurs [6,9]. Most of the sediments eroded at the head end of the field settle out before reaching the tail end. Trout [4] studied on-field distribution of erosion 
and sedimentation in irrigated furrows and found that the erosion rates on the upper quarter of the furrows were 6 to 20 times greater than the average rates from the field. Fernández-Gómez et al. [10] studied the furrow erosion on loamy textured alluvial and clay loam cracking soil and found that the net rates of soil loss in the upper part of the furrow were up to six times higher than the average net rate for the whole furrow. However, as the infiltration rate decreases with time, the flow rate increases and influences the sediment transport at the tail end. Everts and Carter [11] reported that from 40 to $90 \%$ of soil leaving a field is eroded from the last 9 to $15 \mathrm{~m}$ of each furrow.

Mathematical models can predict sediment load under different field conditions and save time and money on field experimental trials. The irrigation-induced erosion can be modeled using empirical or statistical [12-14], conceptual [15-17], and physically based [18-21] models. These models differ in terms of complexity, processes considered, and the data required for model calibration and model use [14]. Of these, the physically based models are based on the solution of conservation of mass and momentum equations for flow and the conservation of mass equation for sediment transport. The physically based models are also termed as process-based models [13] as they still rely on empirical equations to describe erosion processes. Wu and Meyer [18] developed a conceptual and physically based model, ROWERO for simulating transport of nonuniform sediment along flatland furrows and the modeling tool may not be applicable for graded furrows. Strelkoff et al. [19] developed SRFR for simulating flow, soil erosion, and deposition at various points along the furrow using Laursen [22], Yang [23], and Yalin [24] sediment transport equations. However, the SRFR uses numerical technique to solve the flow equations. Trout [4], Bjorneberg et al. [20], and Bjorneberg and Trout [21] used WEPP (Water Erosion Prediction Project) model for predicting flow and sediment transport in furrow irrigation. Review of the supporting documentation and the literature revealed a number of unnecessary and possibly flawed assumptions within the hydraulic components of the WEPP model [25] that need to be focused on for accurate prediction of irrigation-induced erosion.

The hydraulic component of furrow irrigation can be accurately modeled using the irrigation model presented by Mailapalli et al. [26]. They used analytical solution of zeroinertia equations for simulating overland flow and multiple infiltration models such as 2D-Fok [27], 1D-Green Ampt [28] and Kostiakov-Lewis [29] for estimating infiltration. In this paper, we attempted to integrate a quasi-steady state sediment transport model described by Trout and Neibling [30] to the hydraulic component of Mailapalli et al. [26] irrigation model and evaluated performance of model integration for estimating irrigation-induced erosion.

\section{Theoretical Considerations}

Theoretical background of the hydraulic component of the irrigation model [26] and sediment transport model [30] and their integration is briefly described below.
2.1. Overland Flow Module. The governing equations for simulating flow in the furrows are as follows:

(i) conservation of mass equation

$$
\frac{\partial A}{\partial t}+\frac{\partial u}{\partial x} A+\frac{\partial A}{\partial x} u=-q
$$

(ii) conservation of momentum equation

$$
\frac{\partial h}{\partial x}=S_{0}-\frac{u^{2}}{K^{2} R^{4 / 3}}+\frac{q}{g} \frac{u}{A}
$$

where $A(x, t)$ is the wetted cross-sectional area $\left(\mathrm{m}^{2}\right), u(x, t)$ is the flow velocity $\left(\mathrm{m} \mathrm{s}^{-1}\right), t$ is the time (s), $x$ is the distance along the furrow $(\mathrm{m}), q(x, t)$ is the infiltration rate $\left(\mathrm{m}^{2} \mathrm{~s}^{-1}\right)$, $h(x, t)$ is the water depth $(\mathrm{m}), S_{0}$ is the bottom slope $(-), K$ is the Manning-Strickler coefficient (-), $R$ is the hydraulic radius $(\mathrm{m})$, and $g$ is the gravitational constant $\left(\mathrm{m} \mathrm{s}^{-2}\right)$.

\subsection{Infiltration Module. Infiltration rate is calculated by}

$$
q(x, t)=\frac{d I(t)}{d t}
$$

where $I(t)$ is the cumulative infiltration $\left(\mathrm{m}^{3} / \mathrm{m}\right)$, which is determined by (i) 1D-Green Ampt model, (ii) 2D-Fok model, and (iii) Kostiakov-Lewis model. The option for choosing an infiltration equation in the irrigation model can be useful in selecting a better modeling approach for simulating overland flow and infiltration.

(i) 1D-Green Ampt Model. The one-dimensional vertical infiltration depth is estimated by Green and Ampt [31] equation:

$$
\begin{gathered}
I(t)=z(t) \Delta \theta \\
z(t)=\left(h-S_{\mathrm{av}}\right)\left[\ln \left(\frac{z+\left(h-S_{\mathrm{av}}\right)}{\left(h-S_{\mathrm{av}}\right)}\right)\right]-K_{s} t,
\end{gathered}
$$

where $z(t)$ is the vertical depth of the wetting front $(\mathrm{m}) \Delta \theta=$ $\left(\theta_{s}-\theta_{i}\right)$ is the change in moisture content $\left(\mathrm{m}^{3} \mathrm{~m}^{-3}\right), \theta_{s}$ is the saturated moisture content $\left(\mathrm{m}^{3} \mathrm{~m}^{-3}\right), \theta_{i}$ is the initial moisture content $\left(\mathrm{m}^{3} \mathrm{~m}^{-3}\right), K_{s}$ is the satiated hydraulic conductivity $\left(\mathrm{m} \mathrm{s}^{-1}\right)$, and $S_{\mathrm{av}}$ is the effective suction head at the wetting front $(\mathrm{m})$.

(ii) 2D-Fok Infiltration Model. The general equation for 2Dinfiltration [27] is given by

$$
I_{2 D}(t)=\left(2 h x_{h}+b z+\frac{1}{2} \pi x_{h} z\right) \Delta \theta
$$

where

$$
x_{h}=\left[\frac{2 K_{s}}{\Delta \theta}\left(h-S_{\mathrm{av}}\right) t\right]^{0.5},
$$

where $x_{h}$ is the horizontal wetting front $(\mathrm{m}), b$ is the base width $(\mathrm{m})$, and $K_{s}$ is the hydraulic conductivity $\left(\mathrm{m} \mathrm{s}^{-1}\right)$ of the wetted part of the soil profile. 
(iii) Kostiakov-Lewis (KL) Model [29]. The infiltration equation used to determine $I(t)$ is

$$
I(t)=A_{k} t^{B_{k}}+f_{0} t
$$

where, $A_{k}\left(\mathrm{~m}^{3} \mathrm{~m}^{-1} \mathrm{~s}^{-B k}\right)$ and $B_{k}(-)$ are the fitted parameters; and $f_{0}$ is the basic infiltration rate $\left(\mathrm{m}^{2} \mathrm{~s}^{-1}\right)$.

\subsection{Sediment Transport Model}

2.3.1. Governing Equations. The irrigation-induced soil erosion or deposition over a distance $x$ in furrows is modeled using continuity equation $[30,32]$ :

$$
\frac{\partial q_{s}}{\partial x}+\rho_{s} \frac{\partial(c h)}{\partial t}=D_{r}+D_{l},
$$

where $q_{s}$ is the sediment load $\left(\mathrm{kg} \mathrm{m}^{-1} \mathrm{~s}^{-1}\right), \rho_{s}$ is the mass density of sediment particles $\left(\mathrm{kg} \mathrm{m}^{-3}\right), c$ is the concentration of the sediment in the flow $\left(\mathrm{m}^{3} \mathrm{~m}^{-3}\right), h$ is the flow depth $(\mathrm{m})$, $D_{r}$ is the rill erosion rate $\left(\mathrm{kg} \mathrm{m}^{-2} \mathrm{~s}^{-1}\right), x$ is the distance along the slope $(\mathrm{m}), t$ is the time $(\mathrm{s})$, and $D_{l}$ is the delivery rate of erosion from interrill area $\left(\mathrm{kg} \mathrm{m}^{-2} \mathrm{~s}^{-1}\right)$.

For quasi-steady state $\left(\rho_{s}(\partial(\mathrm{ch}) / \partial t)=0\right)$, condition in furrows and sediment from interrill area is negligible $\left(D_{l}=0\right)$ and (8) can be written as

$$
\frac{d q_{s}}{d x}=D_{r}
$$

Assume $D_{r}=\alpha_{d}\left(T_{c}-q_{s}\right)$ and $D_{c}=\alpha_{d} T_{c}$, and substitute in (9) to yield an equation for sediment load:

$$
q_{s}=T_{c}\left(1-e^{-\left(D_{c} / T_{c}\right) x}\right),
$$

where $\alpha_{d}$ is the first-order reaction coefficient for deposition $\left(\mathrm{m}^{-1}\right), T_{c}$ is the sediment transport capacity $\left(\mathrm{kg} \mathrm{m}^{-1} \mathrm{~s}^{-1}\right)$, and $D_{c}$ is the detachment capacity $\left(\mathrm{kg} \mathrm{m}^{-2} \mathrm{~s}^{-1}\right)$.

2.3.2. Soil Erosion $\left(E_{f}\right)$. Most erosion models recognize that net erosion decreases as sediment load increases. The net erosion, $E_{f}$, is proportional to the difference between the sediment transport capacity $\left(T_{c}\right)$ and sediment load $\left(q_{s}\right)$, resulting in [33].

Consider

$$
\frac{E_{f}}{D_{c}}=1-\frac{q_{s}}{T_{c}} .
$$

2.3.3. Soil Deposition $\left(D_{f}\right)$. Since soil is a porous media, the flow rate decreases with the distance down the furrow, and thus, $D_{c}$ and $T_{c}$ also decrease. As flow rate decreases, $T_{c}$ eventually becomes less than the sediment load, resulting in deposition. The deposition of the soil $\left(D_{f}\right)$ along the furrow is modelled by the following equation [33]:

$$
D_{f}=-\frac{d T_{c}}{d x} \quad\left(T_{c} \leq q_{x}\right)
$$

2.3.4. Estimation of Model Parameters. Equation (10) represents steady-state sediment transport equation for predicting the erosion and deposition processes in the irrigation furrows. It involves several parameters to be estimated before using the equation for modelling sediment transport. The following sections describe the estimation of tractive force or hydraulic shear $(\tau)$, critical shear $\left(\tau_{c}\right)$, soil erodibility coefficient $\left(K_{r}\right)$ and transport capacity $\left(T_{c}\right)$, which are essential for estimation of sediment load $\left(q_{s}\right)$.

(a) Tractive Force $(\tau)$. The tractive force or hydraulic shear acting on the perimeter of the furrow, which is responsible for soil detachment, was calculated by the following tractive force equation [34].

$$
\tau=\gamma R S_{0}
$$

where $\gamma$ is the unit weight of water $\left(\mathrm{N} \mathrm{m}^{-3}\right)$.

(b) Critical Shear Force $\left(\tau_{c}\right)$. The critical hydraulic shear force $\left(\tau_{c}\right)$ is determined by using the following pedotransfer functions [35].

For the soils containing $30 \%$ or more sand,

$$
\tau_{c}=2.67+0.065 \mathrm{PC}-0.058 \mathrm{PVFS},
$$

where PC is the percentage clay and PVFS is the percentage of very fine sand.

For the soils containing less than $30 \%$ sand,

$$
\tau_{c}=3.5
$$

(c) Soil Erodibility $\left(K_{r}\right)$. The soil erodibility $\left(K_{r}\right)$ is determined by using the following pedo-transfer function [35]:

For the soils containing $30 \%$ or more sand,

$$
K_{r}=0.00197+0.00030 \mathrm{PVFS}+0.03863 e^{(-1.84 \mathrm{OM})},
$$

where $\mathrm{OM}$ is the organic matter (\%).

For the soils containing less than $30 \%$ sand,

$$
K_{r}=0.0069+0.134 e^{(-0.2 \mathrm{PC})} .
$$

(d) Transport Capacity $\left(T_{c}\right)$. Sediment transport capacity was calculated by Yalin's equation [24]. Foster and Meyer [15] concluded that Yalin's equation is the most appropriate for shallow flows associated with upland erosion. The Yalin equation is defined as

$$
\begin{gathered}
T_{c}=0.635(\mathrm{SG}) d \rho_{w}{ }^{1 / 2} \tau_{s}{ }^{1 / 2} \delta\left[1-\frac{1}{\beta} \ln (1+\beta)\right] \\
\beta=2.45(\mathrm{SG})^{-0.4}\left(Y_{\mathrm{cr}}\right)^{0.5} \delta \\
\delta=\frac{Y}{Y_{\mathrm{cr}}}-1 \\
Y=\frac{\tau_{s} / \rho_{w}}{(\mathrm{SG}-1) g d}
\end{gathered}
$$

where, SG is the particle-specific gravity, $\rho_{w}$ is the density of water $\left(\mathrm{kg} \mathrm{m}^{-3}\right), d$ is the particle diameter $(\mathrm{m}), Y$ is the 


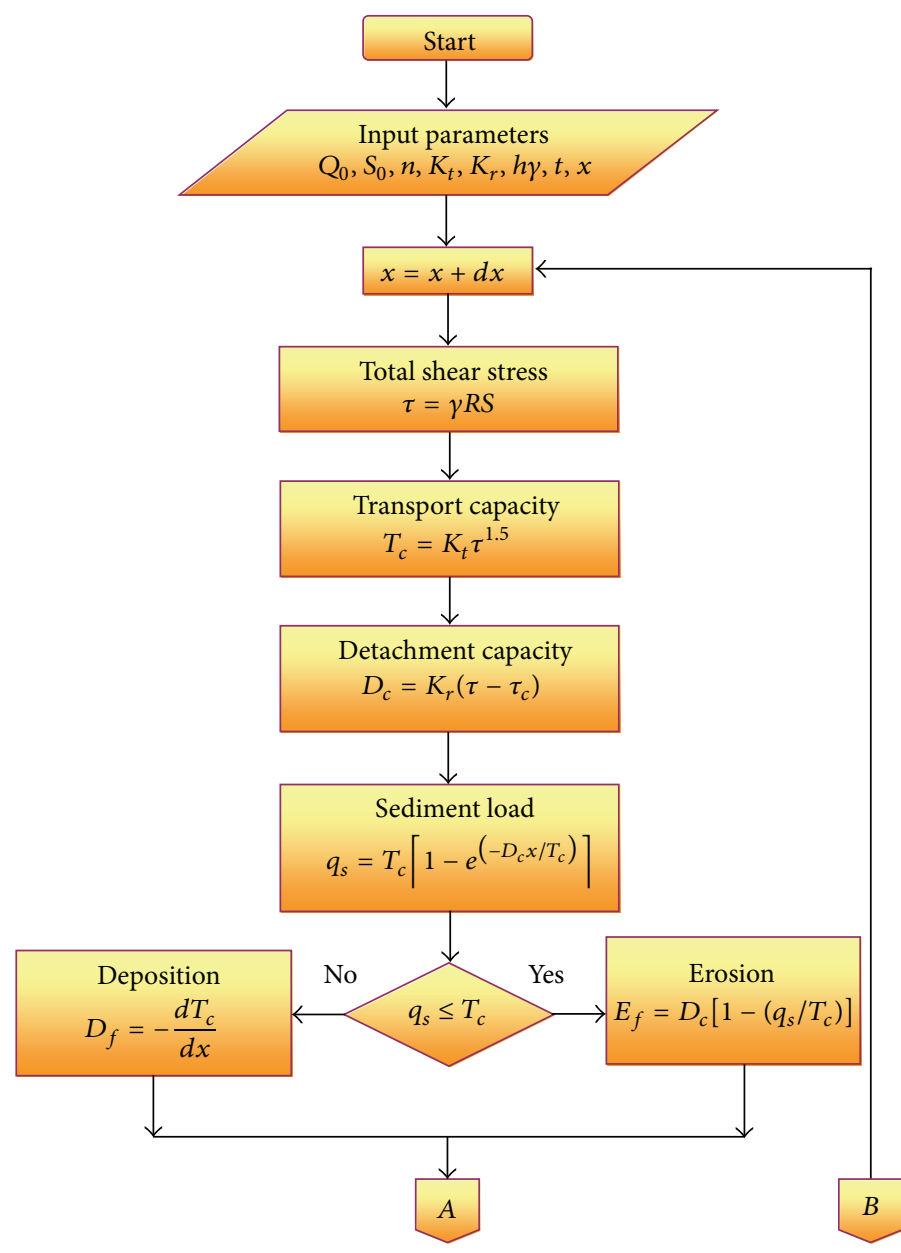

(a)

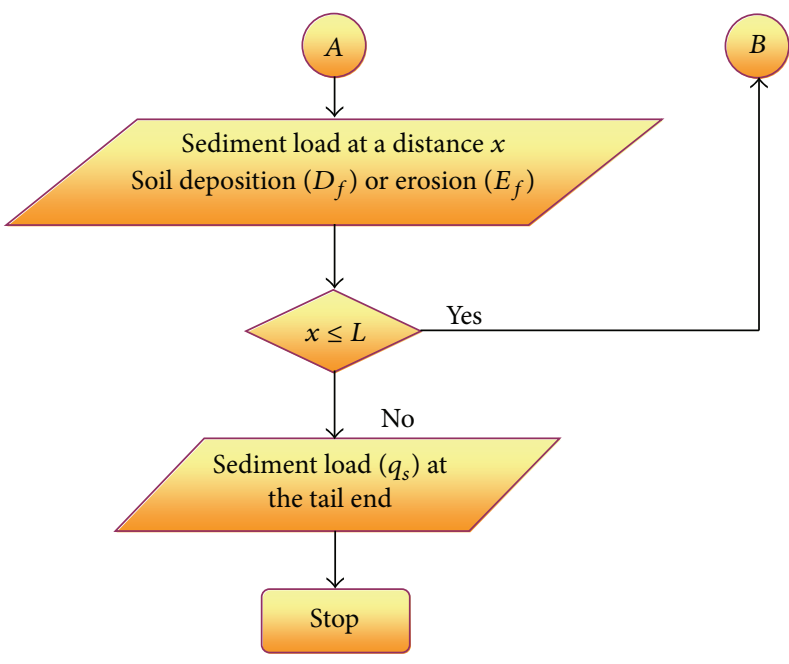

(b)

FIGURE 1: Flowchart showing the working of sediment transport module.

dimensionless shear stress, $Y_{\mathrm{cr}}$ is the dimensionless critical shear from Shield's Diagram, $\tau_{s}$ is the shear stress $\left(\mathrm{N} \mathrm{m}^{-2}\right)$, and $\beta$ and $\delta$ are the dimensionless parameters. Critical shear stress $\left(Y_{\mathrm{cr}}\right)$ was determined by the following regression equation from Shield's Diagram:

$$
\begin{aligned}
\log _{10} Y_{c r}= & 0.002235 x_{c}{ }^{5}-0.06034 x_{c}{ }^{4}+0.20307 x_{c}{ }^{3} \\
& +0.054252 x_{c}{ }^{2}-0.636397 x_{c}
\end{aligned}
$$

where

$$
x_{c}=\log _{10}\left(S_{*}\right), \quad S_{*}=\frac{d \sqrt{(\mathrm{SG}-1) g d}}{4 v},
$$

where $S_{*}$ is the sediment fluid parameter, (m s) and $v$ is the kinematic viscosity of water, $\left(\mathrm{m}^{2} \mathrm{~s}^{-1}\right)$.

When $\tau$ is much greater than the critical shear stress $\left(\tau_{c}\right)$ for transport of detached particles, the Yalin equation (YE) reduced to a simplified equation (MYE) as follows [36]:

$$
T_{c}=K_{t} \tau^{3 / 2}
$$

where $K_{t}$ is the transport coefficient $\left(\mathrm{kg}^{-1 / 2} \mathrm{~m}^{1 / 2} \mathrm{~s}^{2}\right)$.
2.4. Model Integration. In the erosion model, the transport capacity $\left(T_{c}\right)$ and the detachment capacity $\left(D_{c}\right)$ are the two important parameters to be determined at a distance $x$ from the head end of the furrow. The sediment transport capacity $\left(T_{c}\right)$ was determined using the YE and MYE ((18) to (22)). Figure 1 shows the algorithm used to model sediment transport in irrigated furrows using MYE. The algorithm used for YE was the same as MYE (Figure 1). During the simulation run, the irrigation model estimates discharge and determines the sediment transport capacity $\left(T_{c}\right)$ and detachment capacity $\left(D_{c}\right)$. Then, the model estimates sediment load $\left(q_{s}\right)$, erosion $\left(E_{f}\right)$, and deposition $\left(D_{f}\right)$ at a distance $x$ from the head end and time $t$. The sediment load estimation is terminated when the discharge in the furrow is zero.

\section{Model Evaluation}

Performance of the sediment transport module was evaluated for bare and cropped furrow fields. Furrow experiments were conducted on a $4 \mathrm{~m} \times 60 \mathrm{~m}$ plot in the Field Water Management Laboratory, Agricultural and Food Engineering Department, IIT, Kharagpur, India. The soil in the plot was 
TABLE 1: Input data for infiltration and erosion components.

\begin{tabular}{lccc}
\hline Component & Parameter & Bare field & Cropped field \\
\hline & $K_{s}(\mathrm{~m} / \mathrm{s})$ & $1.0 \times 10^{-6}$ & $1.1 \times 10^{-6}$ \\
Infiltration & $S_{\mathrm{av}}(\mathrm{m})$ & 0.13 & 0.13 \\
& $A_{k}\left(\mathrm{~m}^{3} \mathrm{~m}^{-1} \mathrm{~s}^{-B_{k}}\right)$ & $5.0 \times 10^{-4}$ & $5.35 \times 10^{-4}$ \\
& $B_{k}(-)$ & 0.4 & 0.42 \\
& $f_{0}\left(\mathrm{~m}^{2} \mathrm{~s}^{-1}\right)$ & 0.0 & 0.0 \\
\hline \multirow{2}{*}{ Erosion } & $\tau_{c}\left(\mathrm{~N} \mathrm{~m}^{-2}\right)$ & $5.0 \times 10^{-6}$ & 0.0 \\
& $K_{r}\left(\mathrm{~s} \mathrm{~m}^{-1}\right)$ & 0.01 & $1.0 \times 10^{-5}$ \\
& $K_{t}\left(\mathrm{~kg}^{-1 / 2} \mathrm{~m}^{1 / 2} \mathrm{~s}^{2}\right)$ & 2.65 & 0.02 \\
& $\mathrm{SG}$ & $1.8 \times 10^{-5}$ & 2.65 \\
& $d\left(\mathrm{~m}^{-1}\right)$ & $8.9 \times 10^{-6}$ & $2.8 \times 10^{-5}$ \\
\hline
\end{tabular}

TABLE 2: Model performance for simulating sediment loss for bare field.

\begin{tabular}{|c|c|c|c|c|c|c|c|c|c|c|c|}
\hline \multirow{2}{*}{$\begin{array}{l}\text { Date of } \\
\text { irrigation }\end{array}$} & \multirow{2}{*}{$\begin{array}{c}\text { Transport } \\
\text { capacity equation }\end{array}$} & \multirow[b]{2}{*}{ Observed (kg) } & \multicolumn{3}{|c|}{ 2D-Fok and Chiang } & \multicolumn{3}{|c|}{ 1D-Green Ampt } & \multicolumn{3}{|c|}{ KL-infiltration function } \\
\hline & & & $\begin{array}{l}\text { Simulated } \\
(\mathrm{kg})\end{array}$ & $\begin{array}{c}\text { RMSE } \\
\times 10^{-5}(\mathrm{~kg}) \\
\end{array}$ & $I_{a}$ & $\begin{array}{l}\text { Simulated } \\
(\mathrm{kg})\end{array}$ & $\begin{array}{c}\text { RMSE } \\
\times 10^{-5}(\mathrm{~kg})\end{array}$ & $I_{a}$ & $\begin{array}{c}\text { Simulated } \\
(\mathrm{kg})\end{array}$ & $\begin{array}{c}\text { RMSE } \\
\times 10^{-5}(\mathrm{~kg}) \\
\end{array}$ & $I_{a}$ \\
\hline \multirow{2}{*}{ 6th Feb-04 } & $\mathrm{YE}$ & 0.32 & 0.40 & 1.2 & 0.67 & 0.42 & 1.4 & 0.62 & 0.45 & 1.5 & 0.59 \\
\hline & MYE & 0.32 & 0.39 & 1.2 & 0.65 & 0.42 & 1.5 & 0.60 & 0.45 & 1.8 & 0.55 \\
\hline \multirow{2}{*}{ 17th Feb-04 } & YE & 0.47 & 0.60 & 3.1 & 0.13 & 0.61 & 2.9 & 0.13 & 0.65 & 3.2 & 0.15 \\
\hline & MYE & 0.47 & 0.61 & 3.2 & 0.11 & 0.63 & 3.3 & 0.12 & 0.65 & 3.6 & 0.16 \\
\hline \multirow{2}{*}{ 21st Feb-04 } & YE & 0.91 & 0.81 & 1.4 & 0.65 & 0.76 & 1.5 & 0.61 & 0.81 & 1.6 & 0.57 \\
\hline & MYE & 0.91 & 0.72 & 1.4 & 0.65 & 0.72 & 1.6 & 0.59 & 0.76 & 1.9 & 0.55 \\
\hline \multirow{2}{*}{ 29th Feb-04 } & $\mathrm{YE}$ & 1.28 & 0.93 & 1.3 & 0.66 & 0.92 & 1.5 & 0.61 & 0.92 & 1.6 & 0.58 \\
\hline & MYE & 1.28 & 0.94 & 1.3 & 0.65 & 0.93 & 1.6 & 0.54 & 0.91 & 1.9 & 0.55 \\
\hline
\end{tabular}

YE is the Yalin transport equation.

MYE is the modified Yalin transport equation.

sandy loam and contained $69 \%$ sand (61.7\% PVFS), $17 \%$ silt, $14 \%$ clay and $0.43 \%$ organic matter. The bulk density and porosity of the soil were $1.54 \mathrm{~g} / \mathrm{cm}^{3}$ and $40 \%$, respectively. Three free draining furrows of parabolic shape, $40 \mathrm{~m}$ long, $0.30 \mathrm{~m}$ wide, and $0.15 \mathrm{~m}$ deep were fabricated in the experimental plot. The furrows have centre-to-centre distance of $0.8 \mathrm{~m}$ and a slope of $0.5 \%$. The center furrow was considered as study furrow and the two side furrows served as buffer to the center furrow. Three digital flow meters (wheel type) were installed at the inlet of three furrows to set the desired inflow rate to each furrow. Plastic buckets (3-litre capacity) were used to collect run-off at the end of a study furrow at an interval of $10 \mathrm{~min}$.

The run-off samples were oven-dried and the sediment left in each sample was weighed. The run-off rate $\left(\mathrm{m}^{3} / \mathrm{s}\right)$ and the corresponding sediment weight $\left(\mathrm{kg} / \mathrm{m}^{3}\right)$ were used to estimate sediment rate $(\mathrm{kg} / \mathrm{s})$. The details on experiments and data collection procedure are presented by Mailapalli et al. [6]. The three furrows were irrigated at the same time on 6th, 17 th, $21^{\text {st }}$, and 29th February 2004 using constant inflow rates of $0.2,0.3,0.4$, and $0.5 \mathrm{~L} \mathrm{~s}^{-1}$, respectively on bare furrow field. In 2005, sunflower (Helianthus annuus L.) crop was grown on three furrow beds having a plant-to-plant spacing of $45 \mathrm{~cm}$. The three furrows were irrigated on 3rd March, 30th March, 9th April, 16th May and 23rd May, 2005 using 0.7, 0.6, 0.5, 0.4 , and $0.3 \mathrm{~L} \mathrm{~s}^{-1}$, respectively. The furrows were not tilled between irrigations during 2004 and 2005.

Some of the input parameters required for overland flow, infiltration and sediment transport modules were estimated from the field data [37] and these were considered as base line input parameters for model testing. The Green and Ampt hydraulic parameters such as $K_{s}$ and $S_{\mathrm{av}}$ were determined using field data and pedo-transfer functions [38]. The Kostiakov-Lewis parameters $A_{k}, B_{k}$, and $f_{0}$ were estimated by using ring infiltrometer data [37]. The management and geometric parameters for these field conditions were used from [38]. The critical shear $\left(\tau_{c}\right)$ and the soil erodibility coefficient $\left(K_{r}\right)$ were determined using (14), (15), (16), and (17). The estimated values of $K_{r}$ and $\tau_{c}$ were $0.04 \mathrm{~s} \mathrm{~m}^{-1}$ and 0.001 , respectively. The values of SG and $v$ were taken as 2.65 and $8.9 \times 10^{-6} \mathrm{~s} \mathrm{~m}^{-1}$, respectively. The mean diameter $(d)$ of the sediment particle for bare field was $1.8 \times 10^{-5} \mathrm{~m}$ and cropped field was $2.8 \times 10^{-5} \mathrm{~m}$ [37]. The cropped field has coarser particles than the bare field as the irrigations were performed first on the bare field and it may lost most of the fine particles as run-off.

The simulations were first performed using the field observed values of input parameters $\left(K, K_{s}, S_{\mathrm{av}}, A_{k}, B_{k}\right.$, 


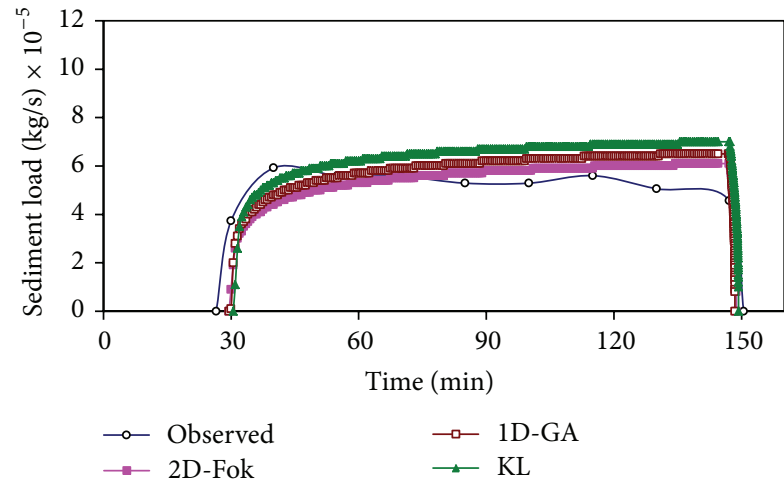

(a)

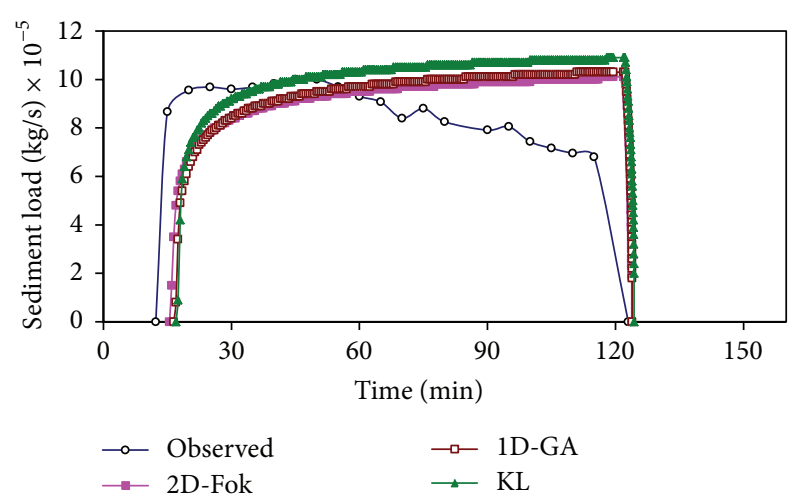

(b)

Figure 2: Comparison of observed and simulated sediment load (using YE) for (a) 6th February 2004 and (b) 17th February 2004 irrigation event.

$\tau_{c}$ and $K_{r}$ ) for estimating sediment load for both bare and cropped field conditions using the three infiltration models. Of these simulations, the best and the worst model performances were selected for both bare and cropped furrow conditions, and model performance was studied graphically. It was assumed that infiltration is the key component of irrigation management and was given first priority for selecting the best and worst simulations, followed by run-off rate, sediment yield, waterfront advance and recession times. Sensitivity analysis was carried out to study the effect of \pm 5 and $\pm 10 \%$ changes in the values of $K_{r}$ and $K_{t}$ on the sediment load, estimated by the YE and MYE.

The performance of the irrigation model for predicting sediment load was evaluated by estimating root mean square error (RMSE) and index of agreement $\left(I_{a}\right)$.

Consider

$$
\begin{gathered}
\text { RMSE }=\sqrt{\frac{\sum_{i=1}^{N}[M(i)-E(i)]^{2}}{N}} \\
I_{a}=1.0-\frac{\sum_{i=1}^{N}(M(i)-E(i))^{2}}{\sum_{i=1}^{N}(|E(i)-\bar{M}|+|M(i)-\bar{M}|)^{2}},
\end{gathered}
$$

where $M(i)$ is the measured value, $E(i)$ is the estimated value, $N$ is the number of data points, and $\bar{M}$ is the mean of the observed values.

\section{Results and Discussion}

The visual observation of the trends between observed and simulated sediment loads (not shown here) by 2D-Fok, 1DGreen Ampt, and KL infiltration equations depicted that the sediment load predictions were not good with the baseline values of $\tau_{c}$ and $K_{r}$. Hence, $\tau_{c}$ was assumed as zero, and $K_{r}$ and $K_{t}$ were considered as calibration parameters for simulating sediment load. During the calibration process, the base values of $K_{r}$ and $K_{t}$ were tuned by increasing or decreasing their base values. For each run, model predicted sediment load was compared with its observed counterpart using the estimated performance indices. Finally, the values of $K_{r}$ and $K_{t}$ were found to be $5.0 \times 10^{-6} \mathrm{~s} \mathrm{~m}^{-1}$ and 0.01 for bare and $1.0 \times$ $10^{-5} \mathrm{~s} \mathrm{~m}^{-1}$ and 0.02 for cropped field conditions, respectively. Table 1 presents the input data used for infiltration and erosion parameters for bare and cropped field conditions.

4.1. Sediment Transport in Bare Furrow Field. The model performance was inconsistent in predicting the sediment load using all three infiltration equations. Furthermore, the YE performed slightly better than the MYE in most of the cases. The 2D-Fok infiltration function resulted in low RMSE and high $I_{a}$ values as compared to those obtained using 1D-Green Ampt and KL infiltration models (Table 2). Thus, the irrigation model performed well in simulating sediment load using the 2D-Fok infiltration function followed by 1DGreen Ampt and KL-infiltration functions. The performance indices (Table 2) suggested that the model performance for sediment load in bare furrow field was the best and the worst for irrigation events of 6th Feb 2004 and 17th Feb 2004, respectively. Therefore, these events were selected for further analysis. Figures 2 and 3 show comparison between observed and simulated outputs for the best (6th February 2004) and the worst (17th February 2004) irrigation events using YE and MYE, respectively.

The irrigation model with YE and MYE predicted initial increase in sediment load well. However, both YE and MYE were not able to predict the decreasing trend of sediment rate with elapsed time. The possible reason could be that the sediment load estimation takes the run-off rate into account which increases with elapsed time. Figures 2 and 3 also show that the model performed equally well using 2D-Fok, 1DGreen Ampt, and KL infiltration models. However, sediment load predictions using the YE were slightly better than the MYE.

4.2. Sediment Transport in Cropped Furrow Field. 2D-Fok infiltration function resulted in lower RMSE values and higher $I_{a}$ values compared to those obtained using 1D-Green Ampt and KL infiltration functions (Table 3). Further, RMSE and $I_{a}$ values also suggested that the irrigation model with YE performed slightly better than that with MYE. Based on the 


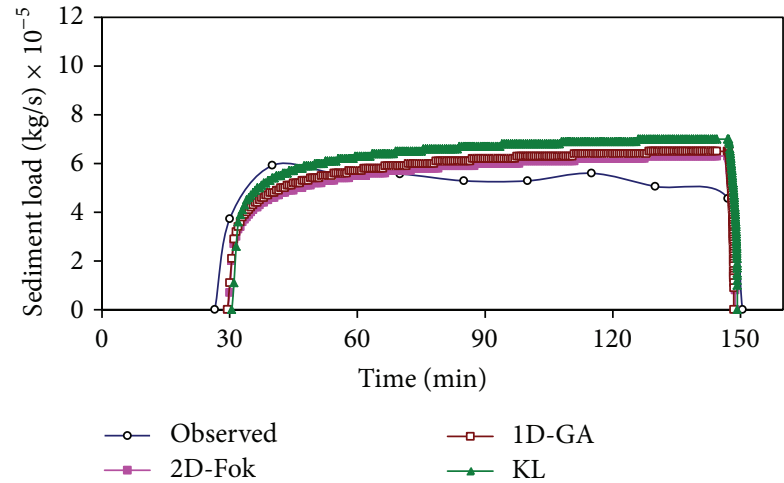

(a)

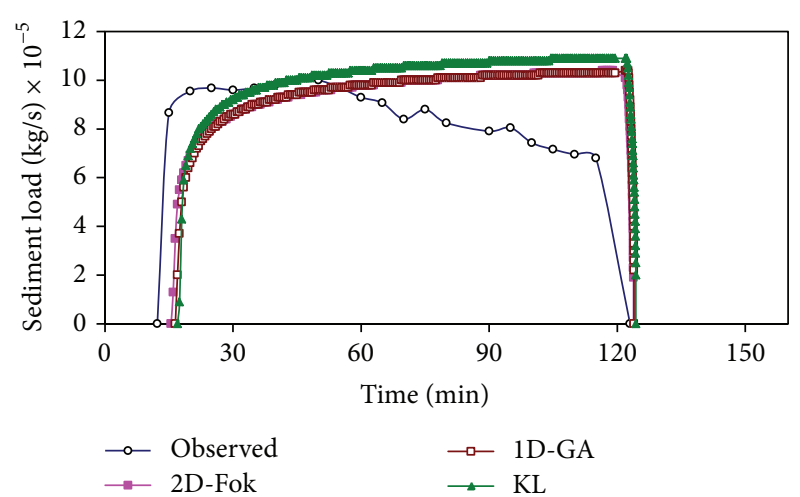

(b)

FIGURE 3: Comparison of observed and simulated sediment load (using MYE) for (a) 6th February 2004 and (b) 17th February 2004 irrigation events.

TABLE 3: Model performance for simulating sediment loss for cropped field.

\begin{tabular}{|c|c|c|c|c|c|c|c|c|c|c|c|}
\hline \multirow{2}{*}{$\begin{array}{l}\text { Date of } \\
\text { irrigation }\end{array}$} & \multirow{2}{*}{$\begin{array}{c}\text { Transport } \\
\text { capacity equation }\end{array}$} & \multirow[b]{2}{*}{ Observed (kg) } & \multicolumn{3}{|c|}{ 2D-Fok and Chiang } & \multicolumn{3}{|c|}{ 1D-Green Ampt } & \multicolumn{3}{|c|}{ KL-infiltration function } \\
\hline & & & $\begin{array}{c}\text { Simulated } \\
(\mathrm{kg})\end{array}$ & $\begin{array}{c}\text { RMSE } \\
\times 10^{-5}(\mathrm{~kg}) \\
\end{array}$ & $I_{a}$ & $\begin{array}{c}\text { Simulated } \\
(\mathrm{kg})\end{array}$ & $\begin{array}{c}\text { RMSE } \\
\times 10^{-5}(\mathrm{~kg}) \\
\end{array}$ & $I_{a}$ & $\begin{array}{c}\text { Simulated } \\
(\mathrm{kg})\end{array}$ & $\begin{array}{c}\text { RMSE } \\
\times 10^{-5}(\mathrm{~kg}) \\
\end{array}$ & $I_{a}$ \\
\hline \multirow{2}{*}{ 3rd Mar-05 } & YE & 1.12 & 1.15 & 8 & 0.55 & 1.18 & 8 & 0.54 & 1.19 & 9 & 0.45 \\
\hline & MYE & 1.12 & 1.17 & 9 & 0.55 & 1.18 & 9 & 0.53 & 1.19 & 9 & 0.44 \\
\hline \multirow{2}{*}{ 30th Mar-05 } & YE & 1.07 & 0.97 & 9 & 0.53 & 0.96 & 9 & 0.51 & 0.95 & 13 & 0.42 \\
\hline & MYE & 1.07 & 0.88 & 9 & 0.54 & 0.90 & 9 & 0.51 & 0.93 & 13 & 0.42 \\
\hline \multirow{2}{*}{ 9th Apr-05 } & YE & 1.02 & 0.93 & 4 & 0.83 & 0.99 & 4 & 0.78 & 1.00 & 6 & 0.72 \\
\hline & MYE & 1.02 & 0.95 & 4 & 0.83 & 1.00 & 4 & 0.73 & 1.04 & 7.5 & 0.69 \\
\hline \multirow{2}{*}{ 16th May-05 } & YE & 0.63 & 0.78 & 3 & 0.85 & 0.79 & 3 & 0.81 & 0.84 & 6 & 0.75 \\
\hline & MYE & 0.63 & 0.77 & 4 & 0.84 & 0.77 & 4.2 & 0.83 & 0.82 & 7 & 0.72 \\
\hline \multirow{2}{*}{ 23rd May-05 } & YE & 0.29 & 0.42 & 4 & 0.83 & 0.47 & 4 & 0.80 & 0.54 & 7 & 0.72 \\
\hline & MYE & 0.29 & 0.46 & 5 & 0.82 & 0.47 & 6 & 0.80 & 0.54 & 8 & 0.70 \\
\hline
\end{tabular}

performance indices, it is clear that the model performance in predicting sediment load was the best and the worst in simulating irrigation events of 16th May and 30th March 2005, respectively. For these two irrigation events, the model predicted sediment load was compared with their observed counterparts and the results are shown in Figures 4 and 5 for YE and MYE, respectively.

Both YE and MYE predicted initial increase in sediment load well. However, as in case of bare furrow condition, both YE and MYE were not able to predict the decreasing trend of sediment rate with elapsed time. The model performed equally well using 2D-Fok, 1D-Green Ampt and KL infiltration equations (Figures 4 and 5). Furthermore, the irrigation model with YE predicted the sediment load slightly better than the one with the MYE (Table 3).

4.3. Sensitivity Analysis of Model Parameters. Sensitivity of the model parameters in predicting sediment load was studied for 16th May 2005 event. The effect of \pm 5 and $\pm 10 \%$ changes in $K_{r}$ and $K_{t}$ (Table 4 ) on the simulated sediment load was estimated by YE and MYE, considering all infiltration functions. The variation in $K_{t}$ did not have much effect on the sediment load whereas the percentage change in $K_{r}$ caused the sediment load change at the same rate (by which $K_{r}$ is changed). Hence, for $2 \mathrm{D}$-infiltration model, $K_{r}$ is the most sensitive parameter for estimating sediment load for both YE and MYE. For 1D-infiltration equation, the effect of change in $K_{t}$ and $K_{r}$ on the sediment yield is the same as the case with $2 \mathrm{D}$-infiltration model. The change in $K_{t}$ had very little effect on the sediment load that resulted with KL infiltration model. The increase in $K_{r}$ increased the sediment load at the same rate for both YE and MYE.

\section{Conclusions}

Irrigation-induced erosion accounts most part of the diffuse agricultural pollution causing downstream impairment and eutrophication. In this study, a steady state sediment transport model was integrated with a physically based furrow irrigation model, which consists of three infiltration equations (2D-Fok, 1D-Green Ampt, and Kostiakov-Lewis). The integrated irrigation model was evaluated for estimating 
TABLE 4: Sensitivity analysis of erosion module parameters.

\begin{tabular}{|c|c|c|c|c|c|c|c|}
\hline \multirow{3}{*}{ Input parameter } & \multirow{3}{*}{ Percentage change } & \multicolumn{6}{|c|}{ Percentage change in sediment load } \\
\hline & & \multicolumn{2}{|c|}{ 2D-Fok and Chiang } & \multicolumn{2}{|c|}{ 1D-Green Ampt } & \multicolumn{2}{|c|}{ KL infiltration function } \\
\hline & & MYE & YE & MYE & YE & MYE & YE \\
\hline \multirow{4}{*}{$K_{t}\left(\mathrm{~kg}^{-1 / 2} \mathrm{~m}^{1 / 2} \mathrm{~s}^{2}\right)$} & $-10 \%$ & 0 & NA & 0.13 & NA & -0.24 & NA \\
\hline & $-5 \%$ & 0 & NA & 0.13 & NA & 0 & NA \\
\hline & $5 \%$ & 0.13 & NA & 0.39 & NA & 0.12 & NA \\
\hline & $10 \%$ & 0.13 & NA & 0.39 & NA & 0.24 & NA \\
\hline \multirow{4}{*}{$K_{r}\left(\mathrm{~s} \mathrm{~m}^{-1}\right)$} & $-10 \%$ & -9.96 & -9.99 & -9.61 & -10 & -9.74 & -10.7 \\
\hline & $-5 \%$ & -4.85 & -4.99 & -4.68 & -4.94 & -4.87 & -4.99 \\
\hline & $5 \%$ & 5.11 & 4.99 & 5.19 & 5.06 & 4.99 & 4.99 \\
\hline & $10 \%$ & 10.09 & 10.58 & 10 & 10.13 & 9.87 & 9.99 \\
\hline
\end{tabular}

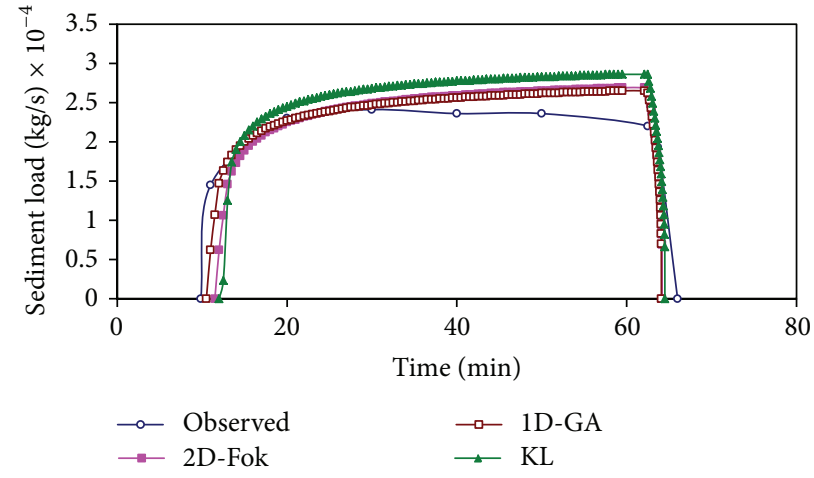

(a)

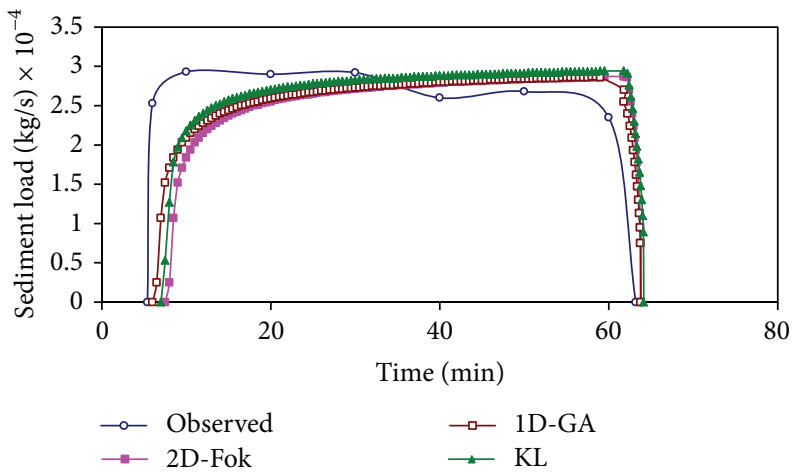

(b)

FIGURE 4: Comparison of observed and simulated sediment load (using YE) for (a) 16th May 2005 and (b) 30 th March 2005 irrigation events.

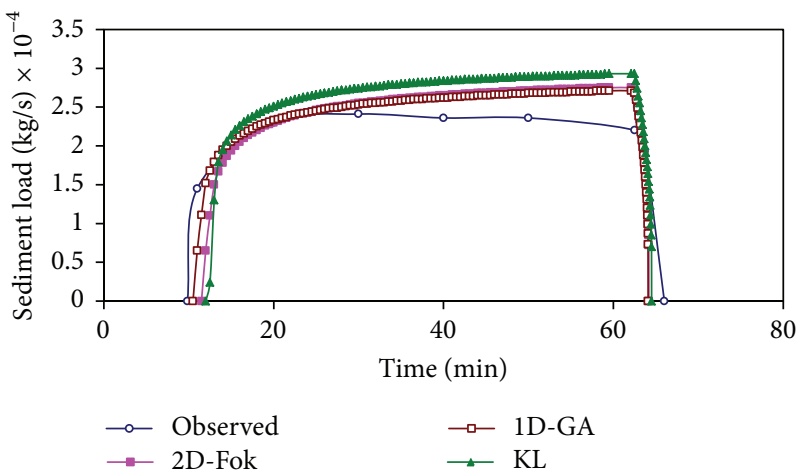

(a)

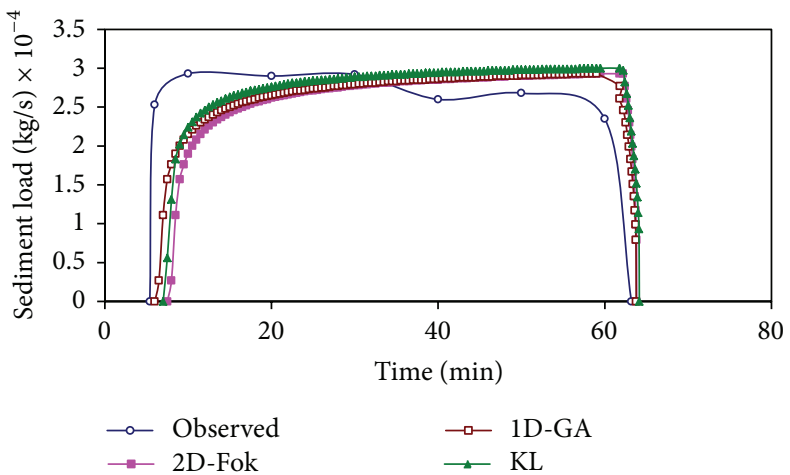

(b)

FIGURE 5: Comparison of observed and simulated sediment load (using MYE) for (a) 16th May 2005 and (b) 30 th March 2005 irrigation event.

sediment load using two sediment transport capacity equations (Yalin and the modified Yalin equations) for bare and cropped field conditions. The sediment load prediction using the Yalin and the modified Yalin equations was found to be identical; however, the modified Yalin equation may be a better choice as it requires less number of input parameters. The sensitivity analysis revealed that the soil erodibility coefficient is the most influential parameter in predicting sediment transport in free drained furrows. However, the irrigation model could not adequately simulate the sediment load in the last phase of irrigation. Although this has a minor impact on the overall sediment load, it will be the subject of future model refinement. The irrigation model uses an analytical solution for zero-inertial flow equations and this compared favourably to the full numerical hydraulic models [39]. This paper describes the procedure for coupling 
the sediment module to the zero-inertial irrigation model and design for simulating infiltration though layered soils [37]. This is one of the advantages of the integrated model for investigating the impact of soil layering on sediment transport. The other advantage is the use of the model as educational tool for studying the effect of various infiltration and sediment capacity equations on the sediment rate. The integrated model can also be used as a management tool to determine optimum water delivery to irrigated furrows or borders for attaining better irrigation performance with minimum soil loss. The modeling approach can also be integrated with nutrient transport models where sediment bound nutrient losses contribute substantially to total nonpoint nutrient losses from agricultural fields.

\section{Acknowledgments}

The authors are grateful to Volkswagen Foundations, Stiftung, Germany for providing financial support which made the realization of this work possible. The technical support for the model development by Prof. G. H. Schmitz and Prof. F. Lennartz is gratefully acknowledged.

\section{References}

[1] Food and Agriculture Organization, AQUASTAT, http://www .fao.org/nr/water/aquastat/water_use/index.stm, 2013.

[2] R. D. Berg and D. L. Carter, "Furrow erosion and sediment losses on irrigated cropland," Journal of Soil \& Water Conservation, vol. 35 , no. 6 , pp. 267-270, 1980.

[3] W. D. Kemper, T. J. Trout, M. J. Brown, and R. C. Rosenau, "Furrow erosion and water and soil management," Transactions of the American Society of Agricultural Engineers, vol. 28, no. 5, pp. 1564-1572, 1985.

[4] T. J. Trout, "Furrow irrigation erosion and sedimentation: on-field distribution," Transactions of the American Society of Agricultural Engineers, vol. 39, no. 5, pp. 1717-1723, 1996.

[5] L. Mateos and J. V. Giráldez, "Suspended load and bed load in irrigation furrows," Catena, vol. 64, no. 2-3, pp. 232-246, 2005.

[6] D. R. Mailapalli, N. S. Raghuwanshi, and R. Singh, "Sediment transport in furrow irrigation," Irrigation Science, vol. 27, no. 6, pp. 449-456, 2009.

[7] P. K. Koluvek, K. K. Tanji, and T. J. Trout, "Overview of soil erosion from irrigation," Journal of Irrigation \& Drainage Engineering, vol. 119, no. 6, pp. 929-946, 1993.

[8] M. J. Brown, D. L. Carter, G. A. Lehrsch, and R. E. Sojka, "Seasonal trends in furrow irrigation erosion in southern Idaho," Soil Technology, vol. 8, no. 2, pp. 119-126, 1995.

[9] T. J. Trout, "Sediment transport in irrigation furrows," in Proceedings of the 10th International Soil Conservation Organization Meeting Held May 24-29, 1999 at Purdue University and the USDA-ARS National Soil Erosion Research Laboratory, D. E. Stott, R. H. Mohtar, and G. C. Steinhardt, Eds., pp. 710-716, 2001.

[10] R. Fernández-Gómez, L. Mateos, and J. V. Giráldez, "Furrow irrigation erosion and management," Irrigation Science, vol. 23, no. 3, pp. 123-131, 2004.

[11] C. J. Everts and D. L. Carter, Furrow Erosion and Topsoil Losses, Current information series no. 586, College of Agriculture, University of Idaho, Moscow, Russia, 1981.
[12] K. J. Fornstrom and J. Borelli, "Design and management procedure for minimising erosion from furrow irrigated cropland," Paper 84-2595, American Society of Association Executives, St. Joseph, Mich, USA, 1994.

[13] R. P. C. Morgan, “The European soil erosion model: an update on its structure and research base," in Conserving Soil Resources: European Perspectives, R. J. Rickson, Ed., pp. 286-299, CAB Int.Oxton, Scotland, UK, 1995.

[14] W. S. Merritt, R. A. Letcher, and A. J. Jakeman, "A review of erosion and sediment transport models," Environmental Modelling and Software, vol. 18, no. 8-9, pp. 761-799, 2003.

[15] G. R. Foster and L. D. Meyer, "Mathematical simulation of upland erosion by fundamental erosion mechanics," Present and Prospective Technology for Predicting Sediment Yield and Sources, USDA, ARS Publication ARS-S40, USDA, Agricultural Research Service, Nat. Tech. Information Service, Springfield, Va, USA, 1972.

[16] M. B. Abbott, J. C. Bathurst, J. A. Cunge, P. E. O'Connell, and J. Rasmussen, "An introduction to the European hydrological system-systeme hydrologique Europeen, "SHE", 1: history and philosophy of a physically-based, distributed modelling system," Journal of Hydrology, vol. 87, no. 1-2, pp. 45-59, 1986.

[17] A. J. Jakeman and G. M. Hornberger, "How much complexity is warranted in a rainfall-runoff model?" Water Resources Research, vol. 29, no. 8, pp. 2637-2649, 1993.

[18] C. C. Wu and L. D. Meyer, "Simulating transport of nonuniform sediment along flatland furrows," Transactions of the American Society of Agricultural Engineers, vol. 32, no. 5, pp. 1651-1661, 1989.

[19] T. S. Strelkoff, A. J. Clemmens, and B. V. Schmidt, SRFR, Version 3.21-a Model for Simulating Surface Irrigation in Borders, Basins and Furrows, USWCL, USDA/ARS, Phoenix, Ariz, USA, 1998.

[20] D. L. Bjorneberg, T. J. Trout, R. E. Sojka, and J. K. Aase, "Evaluating WEPP-predicted infiltration, runoff, and soil erosion for furrow irrigation," Transactions of the American Society of Agricultural Engineers, vol. 42, no. 6, pp. 1733-1741, 1999.

[21] D. L. Bjorneberg and T. J. Trout, "Evaluating WEPP predicted on-field furrow erosion," in Proceedings of the 10th International Soil Conservation Organization (ISCO '99), West Lafayette, Ind, USA, May 1999.

[22] E. M. Laursen, “The total sediment load of streams," Journal of Hydraulics Divison, vol. 84, pp. 1530-1-1530-36, 1958.

[23] C. T. Yang, "Incipient motion and sediment transport," Journal of Hydraulics Divison, vol. 99, no. 10, pp. 1679-1704, 1973.

[24] M. S. Yalin, "An expression for bed-load transportation," Journal of Hydraulics Divison, vol. 89, no. 3, pp. 221-250, 1963.

[25] T. S. Strelkoff and D. L. Bjorneberg, "Hydraulic modeling of irrigation-induced furrow erosion," in Proceedings of the 10th International Soil Conservation Organization Conference, D. E. Stott, R. H. Mohtar, and G. C. Steinhardt, Eds., Sustaining the Global Farm, pp. 699-705, West Lafayette, Ind, USA, May 1999.

[26] D. R. Mailapalli, R. Singh, and N. S. Raghuwanshi, "Physically based model for simulating flow in furrow irrigation. I: model development," Journal of Irrigation and Drainage Engineering, vol. 135, no. 6, pp. 739-746, 2009.

[27] Y. S. Fok and S. H. Chiang, "2-D infiltration equations for furrow irrigation," Journal of Irrigation and Drainage Engineering, vol. 110, no. 2, pp. 208-217, 1984.

[28] M. D. Rao, N. S. Raghuwanshi, and R. Singh, "Development of a physically based 1D-infiltration model for irrigated soils," Agricultural Water Management, vol. 85, no. 1-2, pp. 165-174, 2006. 
[29] W. R. Walker and G. V. Skogerboe, Surface Irrigation: Theory and Practice, Prentice Hall, Englewood Cliffs, NJ, USA, 1987.

[30] T. J. Trout and W. H. Neibling, "Erosion and sedimentation processes on irrigated fields," Journal of Irrigation \& Drainage Engineering, vol. 119, no. 6, pp. 947-963, 1993.

[31] W. H. Green and G. Ampt, "Studies on soil physics. I: the flow of air and water through soils," Journal of Agricultural Sciences, vol. 4, no. 1, pp. 1-24, 1911.

[32] J. P. Bennett, "Concepts of mathematical modelling of sediment yield," Water Resources Research, vol. 10, no. 3, pp. 485-492, 1974.

[33] D. L. Bjorneberg, T. J. Trout, R. E. Sojka, and J. K. Aase, "Evaluating WEPP-predicted infiltration, runoff, and soil erosion for furrow irrigation," Transactions of the American Society of Agricultural Engineers, vol. 42, no. 6, pp. 1733-1741, 1999.

[34] W. H. Graf, Hydraulics of Sediment Transport, McGraw-Hill Book, New York, NY, USA, 1971.

[35] D. C. Flanagan and S. J. Livingston, Eds., "USDA-water erosion prediction project: WEPP user summary," NSERL Rep 11, National Soil Erosion Research Laboratoy, West Lafayatte, Ind, USA, 1995.

[36] S. C. Finkner, M. A. Nearing, G. R. Foster, and J. E. Gilley, "Simplified equation for modeling sediment transport capacity," Transactions of the American Society of Agricultural Engineers, vol. 32, no. 5, pp. 1545-1550, 1989.

[37] D. R. Mailapalli, Development and testing of physically based model for simulating flow and sediment transport in furrow irrigation [Ph.D. thesis], Agricultural and Food Engineering Department, Indian Institute of Technology, Kharagpur, India, 2006.

[38] D. R. Mailapalli, N. S. Raghuwanshi, and R. Singh, "Physically based model for simulating flow in furrow irrigation. II: model evaluation," Journal of Irrigation and Drainage Engineering, vol. 135, no. 6, pp. 747-754, 2009.

[39] G. H. Schmitz and G. J. Seus, "Mathematical zero-inertia modeling of surface irrigation. Advance in borders," Journal of Irrigation and Drainage Engineering, vol. 116, no. 5, pp. 603-615, 1990. 

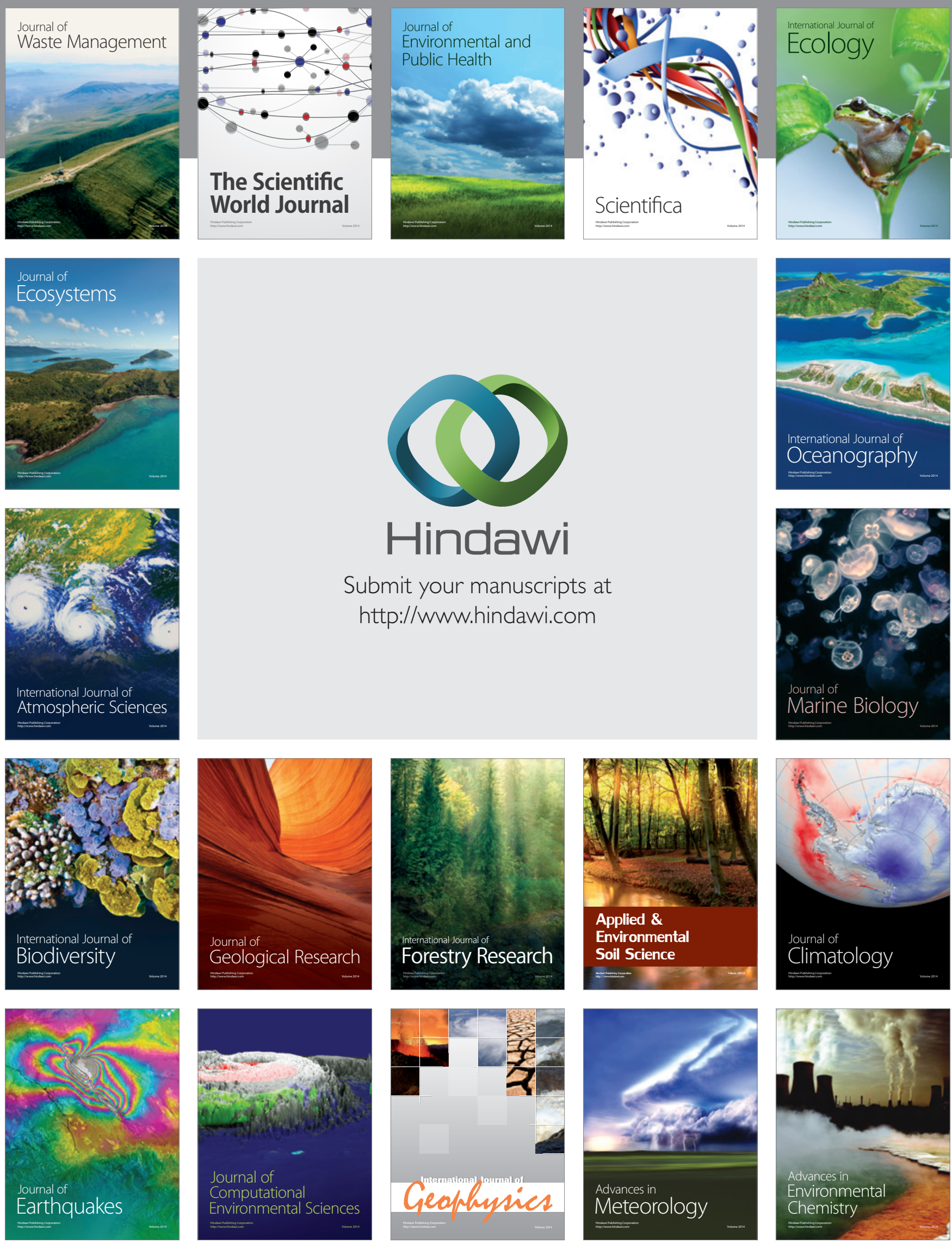